\title{
The Journey towards Inclusion: Exploring the Response of Teachers to the Challenge of Diversity in Schools
}

El viaje hacia la inclusión: explorando la respuesta del profesorado al desafio de la diversidad en las escuelas

A viagem à inclusão: examinando a resposta do professorado ao desafio da diversidade nas escolas

Cecilia María Azorín-Abellán* iD orcid.org/0000-0001-8454-8927

Artículo de investigación

Revista Colombiana de Educación, N. ${ }^{\circ}$ 75. Segundo semestre de 2018, Bogotá, Colombia.

doi: 10.17227/rce.num75-8100

Para citar este artículo: Azorín-Abellán, C. (2018). The Journey towards Inclusion: Exploring the Response of Teachers to the Challenge of Diversity in Schools. Revista Colombiana de Educación, 75, 39-57.

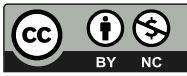

Doctora por la Universidad de Murcia, Profesora del departamento de Didácticas y organización escolar de la Universidad de Murcia, España. 


\begin{abstract}
The general objective of the research presented in this article was to explore the attention to the diversity of students in kindergartens, and primary and high schools in the Region of Murcia (southeast of Spain). This study adopted a methodology of a quantitative nature. The instrument used to collect the data was the Themis Inclusion Tool (Azorín and Ainscow, 2018), which is a Likert scale aimed at teachers formed by three dimensions: contexts, resources and processes. Themis was administered to 545 teachers from 38 schools. This allowed knowing a series of strengths and weaknesses and diagnosing the profile of the schools (barely inclusive, towards inclusion and inclusive), and verifying statistically significant differences according to the variables studied (type of school, location and school stage). According to the results, the strengths focused on the process dimension, making reference to the teaching work, while the weaknesses were found in the contexts dimension, highlighting the scarce commitment between the schools and their communities. Differences were also found according to the type of school and the school stage. Finally, the predominant profile was "towards inclusion". Therefore, the conclusions pointed to the need to continue working for the development of more inclusive practices in schools.
\end{abstract}

\section{Keywords}

inclusion; teacher voices; diversity; self-review; school improvement

\section{Palabras clave}

inclusión; voces del profesorado; diversidad; auto-revisión; mejora escolar
El objetivo general de la investigación que se presenta en este artículo fue explorar la atención a la diversidad del alumnado en escuelas de infantil, primaria y secundaria de la Región de Murcia (sureste de España). Este estudio adoptó una metodología de naturaleza cuantitativa. El instrumento utilizado para recopilar los datos fue Themis Inclusion Tool (Azorín y Ainscow, 2018), que es una escala tipo Likert dirigida al profesorado formada por tres dimensiones: contextos, recursos y procesos. Themis fue administrada a 545 profesores de 38 escuelas. Ello permitió conocer una serie de fortalezas y debilidades y diagnosticar el perfil que tenían las escuelas (apenas inclusivo, hacia la inclusión e inclusivo), y verificar diferencias estadísticamente significativas según las variables estudiadas (tipo de escuela, ubicación y etapa escolar). De acuerdo con los resultados, las fortalezas se concentraron en la dimensión procesos, haciendo referencia al trabajo docente, mientras que las debilidades se encontraron en la dimensión contextos, destacando el escaso compromiso entre las escuelas y sus comunidades. También se encontraron diferencias según el tipo de escuela y la etapa escolar. Finalmente, el perfil predominante fue "hacia la inclusión". Por lo tanto, las conclusiones apuntaron a la necesidad de seguir trabajando para el desarrollo de prácticas más inclusivas en las escuelas.

\section{Resumo}

O objetivo geral da pesquisa apresentada neste artigo foi examinar a atenção à diversidade dos alunos nas escolas infantil, fundamental e médica da regiăo de Murcia (sudeste da Espanha). Este estudo baseou-se em uma metodologia quantitativa. O instrumento utilizado para compilar os dados foi Themis Inclusion Tool (Azorín e Ainscow, 2018), que é uma escala tipo Likert dirigida ao professorado, conformada por três dimensões: contextos, recursos e processos. Themis foi aplicada em 545 professores de 38 escolas. Isso permitiu conhecer uma série de fortalezas e fraquezas, assim como diagnosticar o perfil das escolas (pouco inclusivo, em processo de inclusão e inclusivo) e verificar diferencias estadísticamente significativas segundo as variáveis estudadas (tipo de escola, localização e etapa escolar). De acordo com os resultados, as fortalezas concentraram-se na dimensão processos, relacionada com o trabalho docente, enquanto as debilidades concentraram-se na dimensão contextos, assinalando o escasso compromisso entre as escolas e suas comunidades. Adicionalmente, evidenciaram-se diferenças segundo o tipo de escola e a etapa escolar. Finalmente, o perfil dominante foi "em processo de inclusão". Portanto, as conclusões assinalaram a necessidade de continuar a N. ${ }^{\circ} 75$ trabalhar no desenvolvimento de práticas mais inclusivas nas escolas.

\section{Palavras-chave}

inclusão; vozes do professorado; diversidade; auto-revisão; melhora escolar 


\section{Introduction}

Improving schools and developing inclusion remain inescapable goals of political agendas and educational reforms internationally (Ainscow, Booth, \& Dyson, 2006; OECD, 2015). In this respect, various authors have drawn on the "journey toward inclusion" metaphor. According to Nguyen (2015), inclusion is a journey that questions societies' values and policies. In Confronting Marginalisation in Education, Messiou (2012) offers an interesting framework in which to promote inclusion and sets out that professionals and students are constantly and continuously embarking on voyages of collaboration. The voyages seek to improve schools' capacities through the twofold aim of responding to diversity and of putting into effect inclusive values (Echeita, 2006).

Nowadays, inclusion is focused on the pragmatic idea of education as an emancipatory element that is able to transform children's and young people's lives (UNESCO, 2016b). Inclusion is a process that aims to find effective ways of responding to diversity and identify and remove barriers of presence, participation and achievement, with particular emphasis on those groups of learners who may be at risk of marginalisation, exclusion, or underachievement (Ainscow, Booth, \& Dyson, 2006). At the same time, inclusion seeks to eliminate exclusionary processes from education and negative attitudes or responses to diversity in relation to race, economic status, social class, sexual orientation, ethnicity, religion, gender, language, and attainment, as well as with regard to disabilities (Ainscow, 2015; Messiou et al., 2016; UNESCO, 2009). In fact, one key aspect of inclusive education is that it responds to student diversity by creating learning environments and opportunities for all (Spratt \& Florian, 2015). In this sense, the European Agency for Special Needs and Inclusive Education (2015) emphasizes the importance of empowering teachers to promote a truly inclusive education. Even so, making schools effective for all is probably one of the biggest international challenges of education today (Ainscow et al., 2012b).

The question of how schools can be more effective and inclusive has been widely discussed in recent years (Ainscow, 2012; Echeita et al., 2014; Hehir \& Katzman, 2012; Intxausti, Etxeberria, \& Bartau, 2017; Miles \& Ainscow, 2011; Save the children, 2008). There is a growing number of tools, guides and resources being published that support inclusive education (UNESCO, 2015; UNESCO, 2016a; UNESCO, 2017). The scholarly community has also been clearly influenced by the ethics of school effectiveness and the tendency to make measurements (Sammons \& Bakkum, 2011). In fact, there is growing interest in assessing how the response to diversity is actually taking place in school settings (Arnaiz \& Azorín, 2014). In most cases, the assessment of schools is conducted using tools (questionnaires and scales) that have been designed specifically for this purpose. In a review of 
the literature to search for instruments aimed for teachers, Azorín (2017a) reports that research focuses on: cultural diversity beliefs (Chiner, Cardona, \& Gómez, 2015; López \& Hinojosa, 2016; Vázquez-Montilla, Just, \& Triscari, 2014); effective factors for inclusive education (Brandes et al., 2012; Kitsantas \& Mason, 2012; Sharma, Loreman, \& Forlin, 2012); measures to respond to diversity in schools (Alvarez et al. 2002; Domínguez \& Pino, 2009; Ferrandis, Grau, \& Fortes, 2010; González, 2012; Martínez, 2013); attitudes toward diversity and inclusion (Beacham \& Rouse, 2012; Colmenero, 2006; Forlin et al., 2011; Montánchez, 2014; Vélez, 2013); inclusive education opinions (Bravo, 2013; López, Echeita, \& Martín, 2009); and teacher training for the response to diversity (González-Gil et al., 2013; Lledó, 2009; Pegalajar, 2014).

In brief, teachers have always faced the challenge of how best to respond to the differences among students (Azorín, 2016; Cornejo, 2017; Messiou, 2017; Messiou \& Ainscow, 2015). Therefore, it is important to have tools that enable us to examine this in greater depth. It was with this idea in mind that the Themis Inclusion Tool (Azorín \& Ainscow, 2018) came into being. In this sense, Themis can be presented as an example of a range of similar instruments like the Index for Inclusion (Booth \& Ainscow, 2011) or the Manchester Inclusion Standard (Moore, Ainscow, \& Fox, 2007). Themis seeks to bring together the main issues of responding to diversity within the paradigm of inclusive education. The tool helps teachers to reflect on how they are responding to diversity and, from the point of view of inclusion, identify what lines of change could be implemented to develop contextualized improvement plans. The scale covers three dimensions: contexts, resources and processes. A brief summary of the dimensions and the topics of the different items of each are presented below.

Contexts: This refers to the circumstances surrounding the schools. It is inspired by the ecology of equity, which advocates undertaking changes for greater inclusion within schools, between schools, and beyond schools (Ainscow et al., 2012a). In terms of school improvement, one key issue is context specificity and the institutional, social, geographical and political panorama (Chapman et al., 2012). Thus, the items of this first dimension are related to the socioeconomic situation, cultural diversity, education policy, leadership, pro inclusion values, preventing discriminations, teacher-student relationship, collaboration among teachers, family-school links, community engagement, and networks between schools.

Resources: This dimension is associated to the previous one and refers to personal, institutional and local resources. In this sense, it is important to evaluate the resources schools have available for inclusion (Valenzuela, Guillén, \& Campa, 2014). The items of this dimension go into training resources, human, material, technological and physical resources, as well as the consideration of the school as a resource, and community resources. 
Processes: This dimension focuses on the presence, participation and achievements of children (Ainscow, Booth, \& Dyson, 2006). The items of this last dimension stimulate thinking about celebration of diversity, teaching planning, the education process, variety of methodology, flexible heterogeneous groups, organization of times and spaces, support, and evaluation and transit between stages.

\section{Aims of the Research}

\section{Overall aim}

The overall aim of this paper was to explore the response to the challenge of student diversity in nursery, primary and secondary schools in the Region of Murcia (south-east Spain).

\section{Specific aims}

1. To identify the main strengths and weaknesses deriving from the valuation that teachers make of the attention to diversity in their schools according to the three dimensions used in the study: contexts, resources, and processes.

2. To diagnose the schools' profile (barely inclusive, towards inclusion, and inclusive) according to the responses of the teachers for each dimension.

3. To detect whether there are statistically significant differences for the following variables: type of school (state and private), location (rural, urban, and peri-urban), and scholar stage (nursery, primary, and secondary).

\section{Method}

\section{Participants}

This study adopted a quantitative methodology. The scale (Themis) was administered to 38 schools (25 from nursery and primary education, and 13 from secondary education). Of these, 35 were state schools and 3 were private. Regarding the location, 3 are in rural areas, 4 in peri-urban areas, and 31 in towns. The participants in the study were 545 teachers from the Region of Murcia. The majority were female (66.5\%); $68.4 \%$ were public tenured; $40.3 \%$ had more than 20 years of work experience, and the age range with the highest percentage was 41 to 50 years, with $32.3 \%$. The distribution by phases shows $44 \%$ from secondary education, followed 
by primary education (40.3\%) and nursery education (15.7\%). In terms of occupation, $84.9 \%$ were teachers; $2.4 \%$ were listening and speaking specialists; $4.1 \%$ were special needs teachers; $8.3 \%$ belonged to the leadership team; and $0.3 \%$ were others.

\section{Instrument}

The instrument used to collect the information was the Themis Inclusion Tool (Azorín \& Ainscow, 2018), a Likert-type scale with 65 items and five response options to rate the degree of agreement or disagreement about each of the questions posed; its content validation process was developed by Azorín, Ainscow, Arnaiz \& Goldrick (in press). According to this, Themis was created with a twofold aim: to ascertain teachers' perceptions of response to diversity in their schools and to promote reflection among the teaching body on how to make schools more inclusive by identifying strengths and weaknesses in this regard.

\section{Data collection}

The survey was conducted during the second term of the school year 2015/2016. The proposal was presented in 42 schools, 38 of which agreed to participate. Meetings were held with the leadership teams in which they were given a cover letter outlining the aim of the research and assuring the anonymity of participants. The scale was administered in printed format and schools were provided with a letter-box where teachers could deposit their completed questionnaires. After the data analysis, the information was sent to the schools in the form of a report to the leadership teams.

\section{Data analysis}

Following the influential work of Muijs (2011) about doing quantitative research in education, data were analyzed using the sPSs 23.0 statistical software. Table 1 below shows the cut-off points for delimiting the profiles (barely inclusive, towards inclusion and inclusive) of the dimensions: contexts, resources and processes:

Table 1. Cut-off points

\begin{tabular}{|l|l|c|c|c|c|}
\hline & & Contexts & Resources & Processes & Global scale \\
\hline \multirow{3}{*}{ Cut-off points } & Number of items & 23 & 19 & 23 & \multirow{2}{*}{65} \\
\cline { 2 - 6 } & Barely inclusive & $(1-23)$ & $(24-42)$ & $(43-65)$ & \\
\cline { 2 - 5 } & Towards inclusion & $70-69$ & $1-39$ & $1-69$ & \\
\cline { 2 - 5 } & Inclusive & $96-115$ & $70-69$ & $70-95$ & 325 \\
\hline
\end{tabular}


A barely inclusive profile corresponds to a school that needs to undertake deep reforms to overcome and remove the barriers to inclusion. When a school has this type of profile this means that during the processes of reflection, self-evaluation or the diagnosis more weaknesses than strengths were detected in the response to student diversity. This implies a need for a change in direction and putting into effect actions or plans aimed at developing more inclusive practices in these schools.

A towards inclusion profile places a school as being on the way towards inclusion. While there may still be plausible inclusive practices to bring in, the focus in these cases is more on attending to those aspects which can still be improved in the light of the opinions expressed by the teachers. It is likely that a school with this profile will achieve inclusion if it undertakes ad hoc collective projects to improve the weaknesses detected.

An inclusive profile is associated with the paradigm of an effective and inclusive school. The strengths outweigh the weaknesses. Thus, a school with this profile reflects on cultures, policies and practices that converge towards an education that advocates the analysis of its contexts, resources and processes, that combats discriminating practices, that creates welcoming communities and that seeks to compensate inequalities and fosters the construction of an inclusive society while working to achieve a true education for all scenario.

\section{Results}

Below we offer the results of the research according to the research aims.

Aim 1. To identify the main strengths and weaknesses deriving from the valuation the teachers make of the attention to diversity in their schools according to the three dimensions used in the study: contexts, resources and processes.

In terms of strengths, Table 2 shows the ten items that were most highly scored by teachers, with scores of between 4 and 5 points, where $4=$ agree and 5 = totally agree.

The strengths revealed by the analysis correspond to the dimensions of context (items 8, 9, 12 and 17) and processes (items 44, 46, 47, 60, 61 and 64). The first strength identified corresponded to the development of inclusive values. Elsewhere, teachers take into account not only the result but also the process and identify themselves with values associated with inclusion. Similarly, when they plan their teaching, they take all their students into consideration and use various evaluation tools; they also think that there is a good atmosphere of coexistence within their school and periodically review and update their teaching program. Finally, teachers admitted that they design 
back-up and support activities and encourage families to get involved in the teaching-learning processes of their children and inform students and their families about their process from one educational stage to the next.

Table 2. Strengths identified according to item, and percentages

\begin{tabular}{|c|c|c|}
\hline \multicolumn{2}{|r|}{ Items } & Percentage* \\
\hline 9 & My daily practices foster inclusive values among my students. & 96.9 \\
\hline 61 & $\begin{array}{l}\text { My assessment is based not only on the final grade } \\
\text { but on the progress made by the student. }\end{array}$ & 95.6 \\
\hline 8 & $\begin{array}{l}\text { I identify with values linked to the principle of inclusion (equity, } \\
\text { equality, tolerance, solidarity, social justice, respect for diversity). }\end{array}$ & 95.6 \\
\hline 44 & I plan my teaching taking all the students into account. & 94.7 \\
\hline 60 & I use various tools to evaluate learning. & 94.1 \\
\hline 12 & There is a good coexistence environment in the school. & 93.2 \\
\hline 46 & $\begin{array}{l}\text { I frequently review my teaching programme to } \\
\text { update and adapt it to the class group. }\end{array}$ & 91.7 \\
\hline 47 & I design back-up/curriculum support activities. & 91.0 \\
\hline 17 & I encourage the families to get involved in their children's education. & 91.0 \\
\hline 64 & $\begin{array}{l}\text { The school provides students and families with information } \\
\text { about the transit from one educational stage to the next. }\end{array}$ & 90.5 \\
\hline
\end{tabular}

\section{*Note: of a total of 545 participants.}

Table 3 below shows the ten items worst rated by teachers (with scores of 1 or 2 points: 1 = totally disagree; $2=$ disagree), and these constitute the weaknesses found in attention to diversity.

Table 3. Weaknesses according to item, and percentages

\begin{tabular}{|c|c|c|}
\hline \multicolumn{2}{|r|}{ Items } & Percentage $^{*}$ \\
\hline 22 & $\begin{array}{l}\text { The school is involved in networking projects with } \\
\text { other schools (regional, national or abroad). }\end{array}$ & 60.7 \\
\hline 25 & I collaborate in teaching innovation projects for improving inclusion. & 48.3 \\
\hline 4 & $\begin{array}{l}\text { I believe that the attention to diversity measures under current } \\
\text { legislation respond to the needs of the students at my school. }\end{array}$ & 47.5 \\
\hline 26 & $\begin{array}{l}\text { The staff at the school includes enough specialists/ } \\
\text { auxiliary workers to attend to its student diversity. }\end{array}$ & 47.2 \\
\hline 20 & $\begin{array}{l}\text { During the school year, I carry out activities with } \\
\text { associations that cooperate with the school (those } \\
\text { devoted to disabilities or other purposes). }\end{array}$ & 46.8 \\
\hline 19 & $\begin{array}{l}\text { There are volunteers who collaborate in the education } \\
\text { process (old students, retired people, families and others). }\end{array}$ & 45.0 \\
\hline 33 & $\begin{array}{l}\text { The computer rooms are equipped with enough } \\
\text { computers for the numbers of students. }\end{array}$ & 44.4 \\
\hline 15 & $\begin{array}{l}\text { I perform co-teaching activities (two or more teachers } \\
\text { giving lectures in the same classroom). }\end{array}$ & 42.2 \\
\hline 31 & $\begin{array}{l}\text { I regularly take stock of the materials so as to take } \\
\text { maximum advantage of my school's resources. }\end{array}$ & 40.2 \\
\hline 23 & $\begin{array}{l}\text { The school collaborates with other } \\
\text { socioeducational institutions in the area. }\end{array}$ & 40.2 \\
\hline
\end{tabular}

*Note: of a total of 545 participants. 
The weaknesses found lie in the dimension of contexts (items 4, 15, 19, 20, 22 and 23) and resources (items 25, 26, 31 and 33). The weaknesses reflect no networking between schools at any level; a poor teacher participation in projects linked to inclusion; and a strong disagreement with the means available under current law to address attention to diversity. Other weaknesses that appear are the need for more specialists to attend to diversity, for tighter bonds between associations and for the involvement in the school of stakeholders related to volunteer groups. Teachers also indicated that there were insufficient computer stations for all students and that co-teaching activities were scarce. The lowest percentage was for the inventories of materials that are not made periodically and the scarce collaboration with other institutions in the surrounding area.

Aim 2. To diagnose the schools' profile (barely inclusive, towards inclusion and inclusive) according to the responses of the teachers for each dimension.

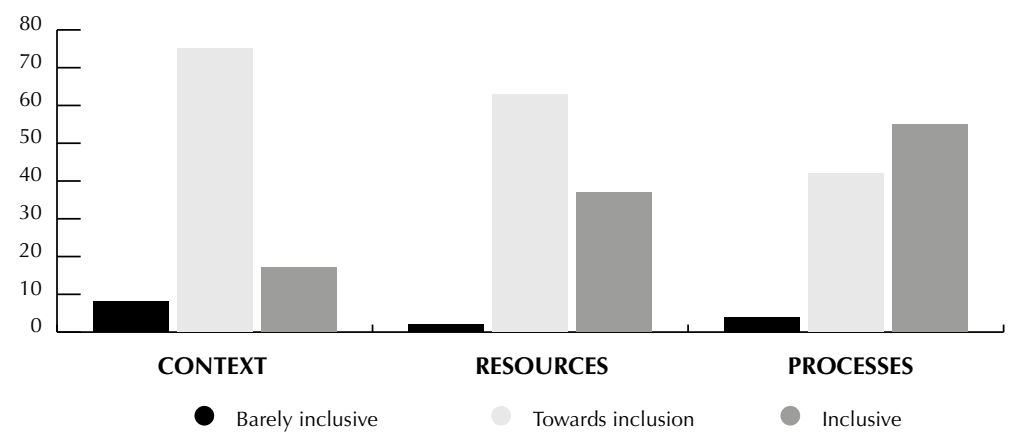

Figure 1. Percentages by profiles and dimensions

The scores given by the teachers for contexts place schools mainly $(76.1 \%)$ in the profile called "towards inclusion," followed by $16 \%$ in "inclusive" and $7.9 \%$ in "barely inclusive". In terms of the resources dimension, $63.1 \%$ fit into the "towards inclusion" profile, 36.7\% appear as "inclusive", and only $0.5 \%$ are "barely inclusive". In the case of the processes dimension, the percentages are closer, with $55.2 \%$ showing an "inclusive" profile and $42.6 \%$ a "towards inclusion" profile. The other $2.2 \%$ are in the "barely inclusive" profile.

Aim 3. To detect whether there are statistically significant differences for the following variables: type of school (state and private), location (rural, urban and peri-urban) and scholar stage (nursery, primary and secondary).

Table 4 below shows the frequency and the percentages of teachers whose responses are associated to each of the profiles according to the type of school. 
Table 4. Significant differences according to type of school

\begin{tabular}{|c|c|c|c|c|}
\hline & \multicolumn{2}{|c|}{ Type of school } & \multirow{2}{*}{$x^{2}(2)$} & \multirow{2}{*}{ p-value } \\
\hline & State & Private & & \\
\hline Contexts & & & 2.22 & .329 \\
\hline Barely inclusive & $36 a(8.0 \%)$ & $7 a(7.4 \%)$ & & \\
\hline Towards & 347a (77.1\%) & $68 a(71.6 \%)$ & & \\
\hline Inclusive & $67 a(14.9 \%)$ & 20a (21.1\%) & & \\
\hline Processes & & & 15.09 & $.001^{* *}$ \\
\hline Barely inclusive & $12(2.7 \%)$ & & & \\
\hline Towards & $206 a(45.8 \%)$ & 26b (27.4\%) & & \\
\hline Inclusive & 232a (51.6\%) & 69b (72.6\%) & & \\
\hline Resources & & & 34.75 & $<.001^{* * *}$ \\
\hline Barely inclusive & $1(0.2 \%)$ & & & \\
\hline Towards & 309a (68.7\%) & 35b (36.8\%) & & \\
\hline Inclusive & 140a (31.1\%) & $60 \mathrm{~b}(63.2 \%)$ & & \\
\hline
\end{tabular}

a-b: different letters in the same row indicate statistically significant differences at the .05 level (Bonferroni). ${ }^{* *} \mathrm{p}<.01{ }^{* * *} \mathrm{p}<.001$.

The information in Table 4 above shows that there are statistically significant differences in both the processes and resources according to the type of school. Specifically, the percentage in processes for the inclusive profile for private schools was $72.6 \%$, versus $51.6 \%$ for state schools and for resources it was $63.2 \%$ for the former versus $31.1 \%$ for the latter.

Table 5 below shows, for the three dimensions, the frequencies and percentages of teachers whose responses matched each profile according to location.

Table 5. Significant differences when taking into account the location of schools

\begin{tabular}{|c|c|c|c|c|c|}
\hline & \multicolumn{3}{|c|}{ Location } & \multirow{2}{*}{$x^{2}(4)$} & \multirow{2}{*}{ P-value } \\
\hline & Rural & Urban & Peri-urban & & \\
\hline \multicolumn{4}{|l|}{ Contexts } & 2.38 & .667 \\
\hline Barely inclusive & $3(9.1 \%)$ & $40(8.2 \%)$ & & & \\
\hline Towards & 24 (72.7\%) & $372(75.9 \%)$ & $19(86.4 \%)$ & & \\
\hline Inclusive & $6(18.2 \%)$ & $78(15.9 \%)$ & $3(13.6 \%)$ & & \\
\hline \multicolumn{4}{|l|}{ Processes } & 2.86 & .582 \\
\hline Barely inclusive & $2(6.1 \%)$ & $10(2.0 \%)$ & & & \\
\hline Towards & $9 \mathrm{~b}(27.3 \%)$ & $22 \mathrm{Ob}(44.9 \%)$ & $3(13.6 \%)$ & & \\
\hline Inclusive & 22b (66.7\%) & $260 b(53.1 \%)$ & $19(86.4 \%)$ & & \\
\hline \multicolumn{4}{|l|}{ Resources } & 8.56 & .073 \\
\hline Barely inclusive & & & $1(4.5 \%)$ & & \\
\hline Towards & $23(69.7 \%)$ & 309 (63.1\%) & $12(54.5 \%)$ & & \\
\hline Inclusive & $10(30.3 \%)$ & $181(36.9 \%)$ & $9(40.9 \%)$ & & \\
\hline
\end{tabular}

a-b: different letters in the same row indicate statistically significant differences at the .05 level (Bonferroni). ${ }^{* * *} \mathrm{p}<.001$. 
From the data in Table 5, the deduction is that there are no statistically significant differences in terms of location. Finally, Table 6 gives the frequency and percentages of the teachers' responses for each dimension according to the scholar stage.

Table 6. Significant differences according to the school stage

\begin{tabular}{|c|c|c|c|c|c|}
\hline & \multicolumn{3}{|c|}{ Scholar stage } & \multirow{2}{*}{$x^{2}(4)$} & \multirow{2}{*}{ p-value } \\
\hline & Nursery & Primary & Secondary & & \\
\hline \multicolumn{4}{|l|}{ Contexts } & 45.52 & $<.001^{* * *}$ \\
\hline Barely inclusive & $2 \mathrm{a}(2.9 \%)$ & $6 a(2.7 \%)$ & 35b (13.7\%) & & \\
\hline Towards & $52 \mathrm{a}(75.4 \%)$ & $160 a(72.7 \%)$ & 203a (79.3\%) & & \\
\hline Inclusive & $15 a(21.7 \%)$ & $54 a(24.5 \%)$ & $18 \mathrm{~b}(7.0 \%)$ & & \\
\hline \multicolumn{4}{|l|}{ Processes } & 61.90 & $<.001^{* * *}$ \\
\hline Barely inclusive & la (1.4\%) & $2 \mathrm{a}(0.9 \%)$ & $9 a(3.5 \%)$ & & \\
\hline Towards & 19a (27.5\%) & $62 \mathrm{a}(28.2 \%)$ & 151b (59.0\%) & & \\
\hline Inclusive & 49a (71.0\%) & 156a (70.9\%) & $96 \mathrm{~b}(37.5 \%)$ & & \\
\hline \multicolumn{4}{|l|}{ Resources } & 55.26 & $<.001^{* * *}$ \\
\hline Barely inclusive & & $1(0.5 \%)$ & & & \\
\hline Towards & $35 a(50.7 \%)$ & $106 a(48.2 \%)$ & 203b (79.3\%) & & \\
\hline Inclusive & $34 a(49.3 \%)$ & $113 a(51.4 \%)$ & 53b (20.7\%) & & \\
\hline
\end{tabular}

a-b: different letters in the same row indicate statistically significant differences at the .05 level (Bonferroni). ${ }^{* * *} \mathrm{p}<.001$.

The table above shows that within the inclusive profile there are statistically significant differences for the three dimensions during secondary schooling, where the lowest percentage is for contexts $(7 \%)$, followed by resources $(20.7 \%)$, and processes $(37.5 \%)$. In this case, it was nursery and primary school teachers who perceived their schools to be more inclusive than secondary school teachers did, with the latter rating the practices in their schools lower in all the dimensions.

\section{Discussion}

The aim of this study was to explore the response to the challenge of student diversity in nursery, primary and secondary schools in the Region of Murcia. It delved into the strengths and weaknesses that teachers face in their response to diversity and, therefore, in their journey towards inclusion. Other studies exist in this context that address teachers' self-assessment education processes (Arnaiz \& Azorín, 2014) and the implementation of improvement plans (Arnaiz, Azorín, \& García, 2015). However, it is not only important to evaluate the processes in schools in order to be able to adopt measures to change and improve, but also to study the contexts the schools find themselves in and the resources available to them to 
respond to diversity. As laid out in the theoretical grounding in this paper, research has been conducted in Spain to ascertain teachers' concepts regarding the inclusion process and to identify segregation, integration and inclusion stances (López et al., 2009). Our research, however, offers schools another type of diagnosis about their current situation and the improvements that can be made in terms of inclusion, which can be considered to be an original contribution to this area of knowledge. Far from seeking to distinguish good and bad schools, the aim is to draw up a map of the current state of the response to diversity on the basis of the profiles established. From there, work can be undertaken to (1) alleviate the weaknesses detected in the schools categorized as barely inclusive; (2) seek new formulas to pave the way forward for those schools fitting into the towards inclusion profile; and (3) maintain the good practices in effect in the inclusive schools. In this, we agree with Darretxe et al. (2013) that, in order to advance effectively in inclusion, one has to start from the current situation of each school. Hence, it is necessary to create interruptions in which to reconsider the day-to-day work in the schools and explore ways of developing more inclusive practices (Ainscow, 2005).

Noteworthy among the main strengths found was how much teachers identified with values associated with inclusion and that their praxis fosters inclusive values among students. Indeed, the furtherance of these values is considered key in developing more inclusive schools (Booth \& Ainscow, 2011). Another positive factor to emerge from the findings is that teachers take into account all their students when planning their teaching and periodically review their teaching programme. Among the items that scored most highly was the readiness of families to involve themselves in their children's education. In this sense, building collaboration bridges with families contributes to the school-without-walls paradigm proposed by Santos-Guerra and De La Rosa (2013), where families have an active and leading role to play in the school institution. Another strength to appear from the findings was the transit between scholar stages. There is a pedagogical current today known as "scholar transit," which supports the need to accompany students and their families during this process (Perry, Dockett, \& Petriwskyj, 2014).

Regarding the weaknesses detected, it was observed that a large number of schools did not engage in support and collaboration networks with other schools on their area. Although there is work going on to set up these type of networks in Spain, there is still much to be done before they become part of the reality of our education system. However, in other countries, like the United Kingdom, this is a well established practice in schools (Ainscow, 2016; Muijs, Ainscow, Chapman, \& West, 2011). According to Azorín and Muijs (2017), networks can be seen as conduits for educational change and inclusion development, and also as a "mirror" 
wherein the present and future of education takes place. Other weaknesses detected had to do with the links between schools and communities, local associations and volunteers. Schools have to overcome barriers and look beyond the school gates, which means increasing collaboration with local communities (Azorín, 2017b; Dyson \& Todd, 2011). One feature that highlighted the scarce collaboration culture in the teachers surveyed was the absence of co-teaching actions. In this way, authors like Rodríguez (2014) have emphasised the benefits of co-teaching as a strategy for improving education and improvement, and others, like Ainscow (2011), insist on the importance of promoting a more collaborative culture within which teachers support one another.

In terms of the profile of the schools in our survey, it was noted that, within the dimensions of contexts and resources, the scores were mainly within "towards inclusion". This reflects that teachers value their schools highly and believe that, in general, their institution is on the right path towards developing more inclusive practices. As regards processes, the highest percentage was for the "inclusive" profile. Nevertheless, these data should be viewed with caution, since many of the items in this dimension are direct questions about the actions of the teachers, so the social desirability of providing suitable answers needs to be considered.

Finally, some statistically significant differences were observed for processes and resources according to the type of school, with a more optimistic perception of inclusion being shown by teachers in private schools than in state schools. This is different to the findings of research by León and Arjona (2011) in private schools in Andalusia, which reported insufficient resources for inclusion that did not adapt to the students' needs. There were no significant differences for location. However, the results obtained in the study of Callado, Molina, Pérez, and Rodríguez (2015) demonstrate that rural areas do not take full advantage of the context they are in to favour inclusion processes and continue to develop proposals that are merely integrative. To conclude, differences were observed within the inclusive profile for the three dimensions in secondary schools compared to nursery and primary, indicating that these are more inclusive than secondary schools. This is in agreement with Bravo (2010), who reported that there were more inclusive practices in primary than secondary schools.

\section{Conclusion, Limitations and Strengths of the Study}

As is apparent throughout this paper, improving schools and developing inclusion are two of the aims on the world agenda of education (Ainscow, Booth, \& Dyson, 2006). So how schools can overcome the barriers to better inclusion is a recurring issue in the literature. However, in order to be aware of the strengths and weaknesses in schools and, in particular, those of the 
professionals who work there (leadership teams and teachers) efficient tools are needed to detect the positive and negative aspects of attention to student diversity. This is important to ascertain what is being done well and what requires improvement and also to make teachers more aware of their actual situation. In this sense, Themis proved of great help in fostering reflection by teachers about the contexts, resources and processes that underpin their education and affect inclusion (Azorín \& Ainscow, 2018).

Thinking on the overall research aim associated to the exploration of the teacher response to the student diversity challenge in schools, in terms of the strengths and weaknesses in the schools of Murcia, the conclusion drawn from our analysis is that the main strengths are to be found in the processes dimension, which indicates that teachers value their own teaching highly. In contrast, most weaknesses were detected in the contexts dimension, and especially the area of community engagement with the school, and vice versa. This points to a need for collaborative practices that bring together the social and professional capital in the schools' surrounding area and to foster more exchanges with other schools, institutions, associations and volunteer networks (Azorín, 2017b).

The profile "barely inclusive" was scored low in the three dimensions considered (contexts, resources and processes), while "towards inclusion" was scored highest for contexts and resources, and "inclusive" for processes. The conclusion in this respect is that the schools in this study and the teachers responding are in the main on the way towards inclusion. This is encouraging but it makes clear too that work is still necessary to get the "inclusive" profile into first position for all the dimensions.

Similarly, it is unquestionable that variables such as school type, location and scholar stage demand different ways of addressing inclusion, so the response to diversity must be treated according to the educational context and the conditioning factors (Echeita et al., 2014).

Finally, the sample was chosen on the basis of accessibility, which may be considered as a limitation as there were only 3 private schools compared to 35 state schools. An evaluation of statistically significant differences between the two types of schools would probably require a more balanced sample to compensate some of the assertions in both categories. Likewise, the total population (545 teachers) came from a specific area, although it should be stated that this was a pioneer study for the Region of Murcia, where it is hoped that future studies will comprise larger samples and hence greater representativeness. At the same time, there has to be a recognition of the limitations of only having teacher perceptions while there are other instruments, such as the Index for Inclusion (Booth \& Ainscow, 2011), that encourages schools to compare the views of different stakeholders, including students and parents. 


\section{References}

Ainscow, M. (2005). Developing inclusive education systems: What are the levers for change? Journal of Educational Change, 6, 109-124.

Ainscow, M. (2011). Some lessons from international efforts to foster inclusive education. Innovación Educativa, 21, 55-74.

Ainscow, M. (2012). Haciendo que las escuelas sean más inclusivas: lecciones a partir del análisis de la investigación internacional. Revista de Educación Inclusiva, 5(1), 39-49.

Ainscow, M. (2015). Struggling for equity in education: The legacy of Salamanca. In F. Kiuppis \& R. S. Hausstätter (Eds.), Inclusive education twenty years after Salamanca (pp. 41-55). New York, NY: Peter Lang.

Ainscow, M. (2016). Collaboration as a strategy for promoting equity in education: Possibilities and barriers. Journal of Professional Capital and Community, 1(2), 159-172.

Ainscow, M., Booth, T., \& Dyson, A. (2006). Improving schools, developing inclusion. London: Routledge.

Ainscow, M., Dyson, A., Goldrick, S., \& West, M. (2012a). Developing equitable education systems. London: Routledge.

Ainscow, M., Dyson, A., Goldrick, S., \& West, M. (2012b). Making schools effective for all: Rethinking the task. School Leadership and Management, 32(3), 197-213.

Álvarez, V., Rodríguez, A., García, E., Gil, J., López, I., Romero, S., \& Padilla, M. T. (2002). La atención a la diversidad en los centros de enseñanza secundaria: estudio descriptivo en la provincia de Sevilla. Revista de Investigación Educativa, 20(1), 225-245.

Arnaiz, P., Azorín, C., \& García, M. P. (2015). Evaluación de planes de mejora en centros educativos de orientación inclusiva. Profesorado, Revista de Currículum y Formación del Profesorado, 19(3), 326-346.

Arnaiz, P., \& Azorín, C. (2014). Autoevaluación docente para la mejora de los procesos educativos en escuelas que caminan hacia la inclusión. Revista Colombiana de Educación, 67, 227-245.

Azorín, C. (2016). La respuesta a la diversidad del alumnado en el contexto inglés: un estudio de casos. Enseñanza \& Teaching, 34(2), 77-91.

Azorín, C. (2017a). Análisis de instrumentos sobre educación inclusiva y atención a la diversidad. Revista Complutense de Educación, 28(4), 1043-1060.

Azorín, C. (2017b). Redes de colaboración entre escuelas inglesas para la mejora de la inclusión socioeducativa. Profesorado, Revista de Currículum y Formación del Profesorado. Número Extraordinario, 29-48.

Azorín, C., \& Muijs, D. (2017). Networks and collaboration in Spanish education policy. Educational Research, 59(3), 273-296. 
Azorín, C., \& Ainscow, M. (2018). Guiding schools on their journey towards inclusion. International Journal of Inclusive Education, 1-18.

Azorín, C., Ainscow, M., Arnaiz, P., \& Goldrick, S. (in press). A tool for teacher reflection on the response to diversity in schools. Profesorado, Revista de Currículum y Formación del Profesorado.

Beacham, N., \& Rouse, M. (2012). Student teachers' attitudes and beliefs about inclusion and inclusive practice. Journal of Research in Special Education Needs, 12(1), 3-11.

Booth, T., \& Ainscow, M. (2011). Index for inclusion. Developing learning and participation in schools. Bristol: CSIE.

Brandes, J., Mcwhirter, P., Hary, K., Crowson, M., \& Millsap, C. (2012). Development of the Indicators of Successful Inclusion Scale (ISIS): Addressing ecological concerns. Teacher Development: An International Journal of Teachers' Professional Development, 14(4), 463-488.

Bravo, L. I. (2010). Prácticas inclusivas en el aula: validación de un instrumento para conocer la perspectiva del alumnado de primaria y secundaria. Revista Electrónica Actualidades Investigativas en Educación, 10(3), 1-20.

Bravo, L. I. (2013). Percepciones y opiniones hacia la educación inclusiva del profesorado y de los equipos directivos de los centros educativos de la Dirección Regional de Enseñanza de Cartago en Costa Rica (Doctorate thesis). Universidad de Alicante, Spain.

Callado, J. A., Molina, M. D., Pérez, E., \& Rodríguez, J. (2015). Inclusive education in schools in rural areas. New Approaches in Educational Research, 4(2), 107-114.

Chapman, C., Armstrong, P., Harris, A., Muijs, D., Reynolds, D., \& Sammons, P. (2012). Conclusion. In C. Chapman, P. Armstrong, A. Harris, D. Muijs, D. Rynolds, \& P. Sammons (Eds.), School effectiveness and improvement research, policy and practice. Challenging the orthodoxy? (pp. 230-245). London: Routledge.

Chiner, E., Cardona, M. C., \& Gómez, J. M. (2015). Teachers' beliefs about diversity: An analysis from a personal and professional perspective. New Approaches in Educational Research, 4(1), 18-23.

Colmenero, M. J. (2006). Análisis de las percepciones del profesorado de Educación Secundaria sobre los procesos de atención a la diversidad. Su incidencia en la formación. Profesorado. Revista de currículum y formación del profesorado, 10(2), 1-15.

Cornejo, C. (2017). Respuesta educativa en la atención a la diversidad desde la perspectiva de profesionales de apoyo. Revista Colombiana de Educación, 73, 75-94.

Darretxe, L., Goikoetxea, J., \& Fernández, A. (2013). Análisis de prácticas inclusivas y exclusoras en dos centros educativos del País Vasco. 
Revista Electrónica Actualidades Investigativas en Educación, 13(2), $1-30$.

Domínguez, J., \& Pino, M. (2009). Evaluación de las medidas de atención a la diversidad en la educación primaria en Galicia: impacto escolar. Revista Española de Orientación y Psicopedagogía, 20(2), 123-134.

Dyson, A., \& Todd, L. (2011). Beyond the school gates. Can full service and extended schools overcome disadvantage? London: Routledge.

Echeita, G. (2006). Educación para la inclusión o educación sin exclusiones. Madrid: Narcea.

Echeita, G., Muñoz, Y., Sandoval, M., \& Simón, C. (2014). Reflexionando en voz alta sobre el sentido y algunos saberes proporcionados por la investigación en el ámbito de la educación inclusiva. Revista Latinoamericana de Educación Inclusiva, 8(2), 25-48.

European Agency for Special Needs and Inclusive Education. (2015). Empowering teachers to promote inclusive education. Brussels: The Agency.

Ferrandis, M. V., Grau, C., \& Fortes, M. C. (2010). El profesorado y la atención a la diversidad en la ESO. Revista Educación Inclusiva, 3(2), 11-28.

Forlin, C., Earle, C., Loreman, T., \& Sharma, U. (2011). The sentiments, attitudes and concerns about inclusive education revised (SACIE-R). Scale for measuring pre-service teachers' perceptions about inclusion. Exceptionality Education International, 21(1), 50-65.

González-Gil, F., Martín-Pastor, M. E., Flores, N. E., Jenaro, C., Poy, R., \& Gómez-Vela, M. (2013). Inclusión y convivencia escolar: análisis de la formación del profesorado. European Journal of Investigation in Health, 3(2), 125-135.

González, A. C. (2012). Medidas y estrategias de educación inclusiva: alumnado CON NEE de la ESO en las provincias de Albacete y Murcia (Doctorate thesis). Universidad de Granada, Spain.

Hehir, T., \& Katzman, L. (2012). Effective inclusive schools. Designing successful schoolwide programs. San Francisco, CA: Jossey-Bass.

Intxausti, N., Etxeberria, F., \& Bartau, I. (2017). Effective and inclusive schools? Attention to diversity in highly effective schools in the Autonomous Region of the Basque Country. International Journal of Inclusive Education, 21(1), 14-30.

Kitsantas, A., \& Mason, G. (2012). Teacher Efficacy Scale for Classroom Diversity (TESCD): A validation study. Profesorado, Revista de Currículum y Formación del Profesorado, 16(1), 35-44.

León, M. J., \& Arjona, Y. (2011). Pasos hacia la inclusión escolar en los centros de educación secundaria obligatoria. Innovación Educativa, $21,201-221$. 
Lledó, A. (2009). De la integración a la inclusión de los alumnos y alumnas en los centros escolares de las comarcas de la provincia de Alicante (Doctorate thesis). Universidad de Alicante, Spain.

López, M., Echeita, G., \& Martín, E. (2009). Concepciones sobre el proceso de inclusión educativa de alumnos con discapacidad intelectual en la educación secundaria obligatoria. Cultura y Educación, 21(4), 485-496.

López, M. C., \& Hinojosa, E. F. (2016). Construction and validation of a questionnaire to study future teachers' beliefs about cultural diversity. International Journal of Inclusive Education, 20(5), 503-519.

Martínez, I. (2013). Evaluación de la calidad de los planes de mejora para atender a la diversidad en Educación Secundaria (Doctorate thesis). Universidad de Granada, Spain.

Messiou, K. (2012). Confronting marginalisation in education. A framework for promoting inclusion. London: Routledge.

Messiou, K. (2017). A research in the field of inclusive education: time for a rethink? International Journal of Inclusive Education, 21(2), 146-159.

Messiou, K, Ainscow, M., Echeita, G., Goldrick, S., Hope, M., Paes, I., Sanvodal, M., Simón, C., \& Vitorino, T. (2016). Learning from differences: A strategy for teacher development in respect to student diversity. School Effectiveness and School Improvement, 27(1), 45-61.

Messiou, K., \& Ainscow, M. (2015). Responding to learner diversity: Student views as a catalyst for powerful teacher development? Teaching and Teacher Education, 51, 246-255.

Miles, S., \& Ainscow, M. (2011). Responding to diversity in schools. An inquiry-based approach. London: Routledge.

Montánchez, M. L. (2014). Las actitudes, conocimientos y prácticas de los docentes de la ciudad de Esmeraldas (Ecuador) ante la educación inclusiva. Un estudio exploratorio (Doctorate thesis). Universidad de Valencia, Spain.

Moore, M., Ainscow, M., \& Fox, S. (2007). The Manchester Inclusion Standard. Manchester: Manchester City Council.

Muijs, D. (2011). Doing quantitative research in education with SPSS. London: Sage.

Muijs, D., Ainscow, M., Chapman, C., \& West, M. (2011). Collaboration and networking in education. London: Springer.

Nguyen, X. T. (2015). The journey to inclusion. Rottherdam: Sense Publishers. OECD. (2015). Education policy outlook 2015: Making reforms happen. Paris: OECD Publishing. 
Pegalajar, M. C. (2014). Importancia de la actividad formativa del docente en centros de educación especial. Revista Electrónica Interuniversitaria de Formación del Profesorado, 17(1), 177-192.

Perry, B., Dockett, S., \& Petriwskyj, A. (2014). Transitions to school. International research, policy and practice. London: Springer.

Rodríguez, F. (2014). La co-enseñanza, una estrategia para el mejoramiento educativo y la inclusión. Revista Latinoamericana de Educación Inclusiva, 8(2), 219-233.

Sammons, P., \& Bakkum, L. (2011). Escuelas eficaces, equidad y eficacia docente: una revisión de la literatura. Profesorado, Revista de Currículum y Formación del Profesorado, 15(3), 9-26.

Santos-Guerra, M. A., \& De la Rosa, L. (2013). La escuela sin muros. Las familias del alumnado inmigrante y su participación en la escuela. Málaga: Ediciones Aljibe.

Save the children. (2008). Making schools inclusive. How change can happen. London: Save the children.

Sharma, U., Loreman, T., \& Forlin, C. (2012). Measuring teacher efficacy to implement inclusive practices. Journal of Research in Special Educational Needs, 12(1), 12-21.

Spratt, J., \& Florian, L. (2015). Inclusive pedagogy: From learning to action. Supporting each individual in the context of 'everybody'. Teaching and Teacher Education, 49, 89-96.

unesCo. (2009). Policy guidelines on inclusion in education. Paris: unEsCo.

UNESCO. (2015). Embracing diversity: Toolkit for creating inclusive learning-friendly environments. Paris: unESCO.

UNESCO. (2016a). Training tools for curriculum development. Reaching out to all learners: a resources pack for supporting inclusive education. Geneva: UNESCO.

UNESCO. (2016b). Reaching out to all learners: A resources pack for supporting inclusive education. Geneva: unESCO.

UNESCO. (2017). A guide for ensuring inclusion and equity in education. Paris: UNESCO.

Valenzuela, B. A., Guillén, M., \& Campa, R. (2014). Recursos para la inclusión educativa en el contexto de educación primaria. Infancias Imágenes, 13(2), 64-75.

Vázquez-Montilla, E., Just, M., \& Triscari, R. (2014). Teachers'dispositions and beliefs about cultural and linguistic diversity. Universal Journal of Educational Research, 2(8), 577-587.

Vélez, L. (2013). La educación inclusiva en docentes en formación: su evaluación a partir de la teoría de facetas. Folios, 37, 95-113. 
